\title{
Pengaruh Iklan Humor Dan Loyalitas Pelanggan Terhadap Keputusan Pembelian Kartu Perdana Axis Versi Kembalian
}

\author{
Slamet Maryoso \\ Fakultas Ekonomi dan Bisnis \\ Universitas Bina Sarana Informatika \\ Email: slamet.sey@bsi.ac.id
} \begin{tabular}{ll}
\hline Cara Sitasi: & Maryoso, S. (2019). Pengaruh Iklan Humor dan Loyalitas Pelanggan Terhadap Keputusan \\
& Pembelian Kartu Perdana Axis Versi Kembalian. Widya Cipta, 3(1), 99-104.
\end{tabular}

\begin{abstract}
The new mass media emerging lately can have a positive effect on the business world. Entrepreneurs can more easily introduce their products through the media, especially television. Products can be better known to the public if they use different and unique ads in terms of attracting consumers' attention. Ads with an element of humor are one of the choices that advertisers can use to attract potential customers. Attractive ads must be accompanied by the quality of products offered by the company. Quality and service for products is one of the determining factors in terms of consumer loyalty. Consumers will make purchasing decisions on a product if the product is attractive and needed. By using the research path analyst method regarding the influence of humor advertising and customer loyalty on purchasing decisions can be known. On the other hand, this research is also useful for the marketing staff involved in determining the attitudes and marketing objectives to be achieved. If the quality of the product offered by the company is of good quality and satisfactory customer service, consumers will make product purchases in the future. This of course consumers will use the product for a long time
\end{abstract}

Keywords: humor ads, customers loyalty, buying decision

\section{PENDAHULUAN}

Televisi merupakan media yang paling disukai oleh banyak perusahaan sebagai sarana promosi produknya, walaupun sebenarnya media ini merupakan media yang cukup mahal. Media televisi memiliki keunggulan dimana para konsumen akan lebih mudah dipengaruhi, karena produk yang diiklankan dapat dilihat secara jelas baik fisik maupun kegunaannya. Selain itu televisi merupakan media yang digemari oleh masyarakat karena program yang ditayangkan cukup variatif. Hal ini juga didukung oleh semakin banyaknya stasiun televisi baru bermunculan, yang mencapai puluhan stasiun televisi swasta di Indonesia.

Sepanjang Januari-September 2011 lalu menurut data Nielsen belanja iklan media mencapai Rp 68,47 triliun, atau tumbuh $20 \%$ dari periode sama pada tahun 2010. Ini menunjukkan persaingan industri telekomunikasi kian ketat. Dari total belanja iklan tersebut, industri telekomunikasi menjadi penyumbang terbesar dengan porsi $\mathrm{Rp}$ 5,7 triliun. Angka ini tumbuh 11,7\% dibandingkan periode sama pada tahun 2010 yang sebesar Rp 5,1 triliun. Televisi masih menjadi media yang menarik bagi operator telekomunikasi karena bisa menjangkau pemirsa TV yang mencapai 60 juta jiwa.

Tingginya persaingan antara perusahaan operator seluler dalam memperkenalkan produk mereka melalui bidang periklanan baik yang bertema humor maupun iklan non humor yang belakangan ini semakin menarik untuk diteliti. Penelitian ini berfokus pada iklan humor operator seluler Axis versi kembalian yang telah tayang melalui televisi. Pemilihan iklan ini karena menurut sumber Surabaya Post, PT. Axis Telecom Indonesia tahun ini sedang meningkatan jumlah belanja iklan untuk media televisi dan online. Peningkatan belanja iklan ini nantinya di harapkan dapat meningkatkan pengguna data sebanyak 5 juta pelanggan. Untuk saat ini jumlah pengguna layanan data Axis mencapai 3 juta pelanggan dari total 16 juta pelanggan. Berdasakan uraian dan penjelasannya tersebut maka, penelitian ini merumuskan beberapa masalah yaitu mengenai apakah ada pengaruh iklan humor kartu perdana Axis, loyalitas pelanggan, terhadap keputusan pembelian.

a. Iklan umor

Menurut Morrisan (2010:18) dalam penggunaan iklan melalui media massa memiliki beberapa hal positif yaitu: Iklan melalui media massa dinilai efisien dari segi biaya untuk mencapai konsumen yang luas, Iklan melalui media masa dapat digunakan untuk menciptakan citra suatu merek dan daya tarik simbolis bagi suatu perusahaan. Salah satu bentuk tema iklan yang banyak digunakan adalah humor. Tema ini dipakai dengan harapan bahwa masyarakat akan tertarik memperhatikan iklan dan timbul perasaan senang karena terhibur (Yunita, 2017). Penggunaan 
humor dalam iklan, terbukti mampu menarik perhatian audience serta meningkatkan ingatan akan sebuah iklan (Mirandha, 2017). Tema iklan humor digunakan untuk mendapatkan rasa senang pemirsa terhadap suatu produk, hasil dari rasa senang tersebut dapat menjadikan seseorang mengambil sikap yang akan melakukan tindakan membeli dan menggunakan produk tersebut.

\section{b. Loyalitas Pelanggan}

Menurut Hill dalam Tahuman, (2016) loyalitas adalah perilaku yang ditunjukan dengan pembelian rutin yang didasarkan pada unit pengambilan keputusan. Pembelian rutin dilakukan pada suatu produk atau jasa yang telah di gunakan sebelumnya. Dengan mengetahui kualitas barang konsumen akan melakukan pembelian ulang barang terseut. Menurut Swastha dalam Marullaili, (2013) definisi loyalitas pelanggan adalah kesetiaan konsumen untuk terus menggunakan produk yang sama dari suatu perusahaan. Loyalitas menggambarkan perilaku yang diharapkan sehubungan dengan produk atau jasa. Loyalitas konsumen akan tinggi apabila suatu produk dinilai mampu memberi kepuasan tertinggi sehingga pelanggan enggan untuk beralih ke merek lain.

\section{c. Keputusan Pembelian}

Informasi mengenai produk mendasari proses pebelian sehingga akhirnya muncul suatu kebutuhan, konsumen akan mempertimbangkan dan memahami kebutuhan tersebut, jika penilaian pada produk sudah jelas maka konsumen akan mencari produk tersebut, kemudian akan berlanjut pada evaluasi produk dan akhirnya konsumen akan mengambil keputusan untuk melakukan pemembelian atau memutuskan untuk tidak melakukan pembelian yang disebabkan produk terseut tidak sesuai dan mempertimbangkan atau menunda pembelian pada masa mendatang (Dinawan, 2010). Keputusan pembelian adalah tindakan yang diambil oleh konsumen dalam memilih untuk membeli atau tidak membeli suatu produk bedasarkan berbagai faktor yang mempengaruhi konsumen dalam melakukan pembelian suatu produk atau jasa (Fajriyani, 2018). Banyak hal yang menjadi pertimbangan konsumen dalam hal melakukan proses pembelian. Pertimangan tersebut didasari atas kebutuhan dan kwalitas barang yang di butuhkan.

Seseorang akan menentukan keputusan pembelian pilihannya berdasarkan manfaat dan biaya yang harus dikeluarkan. Konsumen akan memilih produk yang memberikan manfaat paling besar sesuai dengan harga yang dibayarkan. Kothler dalam bukunya menjelaskan bahwa keputusan dalam membeli merupakan tahap proses keputusan dimana konsumen secara aktual melakukan pembelian produk. Konsumen sebagai pelaku utama dalam proses pembelian selalu menjadi perhatian produsen (Kothler, 2014). Dengan begitu kualitas produk akan menjadi perhatian yang utama bagi sebuah perusahaan.

\section{METODOLOGI PENELITIAN}

Berdasarkan jenis penelitian yang di teliti, teknik dan alat yang digunakan dalam penelitian ini adalah penelitian deskriptif kuantitatif. Penelitian kuantitatif merupakan metode untuk menguji teori-teori tertentu, dengan cara menguji hubungan antar variabel. Sugiyono $(2007,15)$ menjelaskan bahwa penelitian kuantitatif digunakan untuk mengetahui hubungan suatu variabel independen terhadap variabel dependen dalam suatu penelitian serta seberapa besar pengaruhnya dengan tujuan untuk menguji hipotesis yang telah ditetapkan. Sementara hasil suatu penelitian dapat di golongkan menjadi dua yaitu hasil data kualitatif dan data kuantitatif. Data kuantitatif adalah data yang berbentuk angka atau data kualitatif yang diangkakan (skoring).

\section{Teknik Pengumpulan Data}

Data primer penelitian ini diambil dengan menyebarkan kuesioner kepada mahasiswa jurusan Kompuer Akuntansi AMIK BSI Cikampek-Karawang. Sample yang dingunaan sebanyak 165 responden dengan margin kesalahan sebesar 5\%. Pemilihan mahasiswa sebagai obyek penelitian karena pertimbangan mudahnya mendapatkan sampel serta memudahkan penelitian. Metode kuesioner dibuat dengan menggunakan skala likert dengan menggunakan lima pilihan jawaban yang telah ditentukan dengan rentang nilai nominal satu sampai dengan lima.

Tabel 1.

Rentang Nilai Skala Jawaban

\begin{tabular}{lll}
\hline No & Jawaban & $\begin{array}{l}\text { Nilai } \\
\text { Skor }\end{array}$ \\
\hline 1. & Sangat Setuju (SS) & 5 \\
2. & Setuju (S) & 4 \\
3. & Ragu-ragu (R) & 3 \\
4. & Tidak Setuju (TS) & 2 \\
5. & Sangat Tidak Setuju (STS) & 1 \\
\hline
\end{tabular}

\section{Teknik Analisa Data}

Teknik analisa data yang digunakan dalam penelitian ini adalah teknik path analysis atau analisa jalur. Path analysis merupakan teknik analisis yang digunakan untuk menganalisis hubungan sebab akibat yang inheren antar variabel yang disusun berdasarkan urutan temporer dengan menggunakan koefisien jalur sebagai besaran nilai dalam menentukan besarnya pengaruh variabel independen exogenous 
terhadap variabel dependen endogenous (Jonathan Sarwono, 2011). Analisis data menggunakan path analysis ini dilakukan melalui serangkaian beberapa tahapan, yaitu membuat model diagram jalur dimana didasarkan oleh hubungan antar variabel yang sedang diteliti.

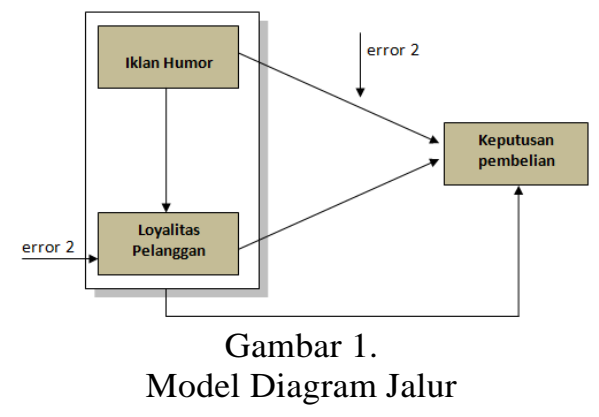

\section{Hipotesis}

Hipotesis penelitian ini adalah mengenai ada atau tidaknya pengaruh iklan humor Axis yang tayang di televisi dan loyalitas pelanggan produk kartu seluler Axis terhadap keputusan pembelian. Hipotesisnya adalah sebagai berikut: Ho : Tidak terdapat pengaruh atas iklan humor Axis yang tayang di televisi dan loyalitas pelanggan kartu seluler Axis terhadap keputusan pembelian. Ha : Terdapat pengaruh atas iklan humor Axis yang tayang di televisi dan loyalitas pelanggan kartu seluler Axis terhadap keputusan pembelian. Dari hipotesis diatas dapat di lambangkan bahwa iklan humor Axis adalah dilambangkan $\mu 1$ loyalitas pelanggan kartu seluler Axis sebagai $\mu 2$ dan keputusan pembelian $\mu 3$ maka hipotesis tersebut dapat di sederhanakan menjadi :Ho : $\mu 1 \mu 2=\mu 3$. Ha : $\mu 1 \mu 2 \neq \mu 3$.

\section{HASIL DAN PEMBAHASAN}

Pengujian atau analisa terhadap statistik deskriptif yang memberikan penjelasan dan gambaran secara umum terhadap penyebaran data yang diperoleh di lapangan. Deskripsi data yang diperoleh disajikan dalam bentuk distribusi melalui nilai minimum, nilai maksimum mean serta standard deviation. Berdasarkan perumusan masalah penelitian, penelitian ini terdiri dari tiga variabel yaitu Iklan Humor (X1), Loyalitas Pelanggan (X2) dan Keputusan Pembelian (X3). Dengan menggunakan jumlah responden sebanyak 156, yang mana telah dikurangi 9 data outlier. Data dari masing variabel diperoleh dari hasil penyebaran kuesioner yang kemudian akan digunakan untuk menguji hipotesis dalam penelitian ini.

\section{Uji Normalisasi Data}

Uji normalitas data digunakan untuk mengetahui apakah populasi data berdistribusi normal atau tidak. Uji ini biasanya digunakan untuk mengukur data berskala ordinal, interval, ataupun rasio. Pengujian dapat dilakukan dengan metode One Sample Kolmogorof-Smirnov dengan taraf signifikansi 0,05 atau dengan menggunakan tabel histogram. Pada tabel histogram, data dikatakan berdistribusi normal jika data tersebut membentuk kurva bel. Dalam penelitian ini, metode yang digunakan adalah metode histogram. Hasil pengujian normalitas data dapat dilihat pada gambar 2 sebagai berikut:

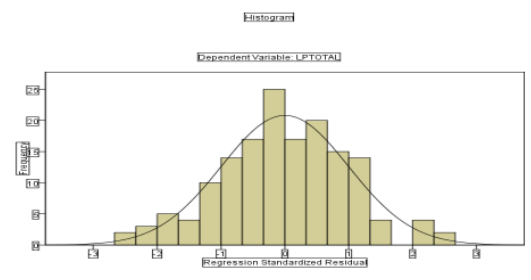

Gambar 2.

Hasil Uji Normalitas Data Sub-Struktur 1

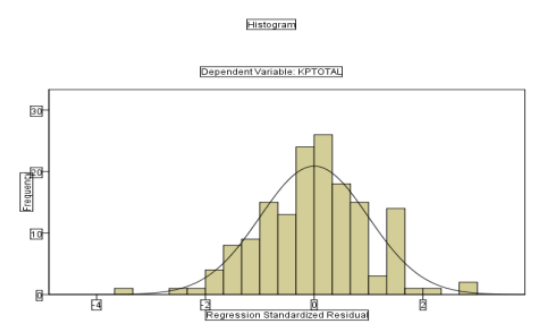

Gambar 3.

Hasil Uji Normalitas Data Sub-Struktur 2

Berdasarkan dari gambar histogram 2 dan 3 diatas, maka data yang digunakan ada kecenderungan membentuk kurva bel. Kesimpulannya adalah model regresi yang sudah dibuat dalam penelitian ini normal dan telah memenuhi semua persyaratan yang diharuskan. Dengan demikian model regresi dalam path analysis ini sudah layak.

\section{Asumsi Klasik}

a. Uji Autokorelasi

Uji autokorelasi dilakukan untuk mengetahui ada atau tidaknya penyimpangan asumsi klasik autokorelasi yaitu korelasi yang terjadi antara residual pada satu pengamatan dengan pengamatan lain pada model regresi. Untuk dapat menyimpulkan apakah terdapat autokorelasi atau tidak, kita harus melihat nilai dU dan dL pada tabel Durbin Watson. Dengan signifikansi 0,05, jumlah data $(n)=156$ serta jumlah variabel independen $(k)=2$, diperoleh nilai dU sebesar 1,760 dan nilai dL sebesar 1,706. Hasil pengujian autokorelasi dapat dilihat pada tabel 2 berikut: 
Tabel 2.

Hasil Uji Autokorelasi Sub-Struktur 1

\begin{tabular}{lccccc}
\hline \multicolumn{5}{c}{ Model Summary $^{\mathbf{b}}$} \\
\hline Modi & $\mathrm{R}$ & $\begin{array}{c}\mathrm{R} \\
\text { Square }\end{array}$ & $\begin{array}{c}\text { Adjusted } \\
\mathrm{R} \\
\text { Square }\end{array}$ & $\begin{array}{c}\text { Std. Error } \\
\text { of the } \\
\text { Estimate }\end{array}$ & $\begin{array}{c}\text { Durbin- } \\
\text { Watson }\end{array}$ \\
$\mathbf{1}$ & $.570^{\mathrm{a}}$ &, 325 &, 321 & 13,896482 & 1,729 \\
\hline a. Predictors: (constant) Iklan Humor... \\
b. Dependent Variable: Loyalitas Pelanggan \\
\hline
\end{tabular}

Dari hasil penghitungan yang telah dilakukan berdasarkan tabel 2, maka diperoleh nilai DurbinWatson sebesar 1,729. Karena, DW < dU atau $1,729<1,760$, maka ada autokorelasi positif. $4-$ $\mathrm{DW}>\mathrm{dL}$ atau 2,271 >1,706, maka tidak ada autokorelasi negatif.

Tabel 3.

Hasil Uji Autokorelasi Sub-Struktur 2

\begin{tabular}{|c|c|c|c|c|c|}
\hline \multicolumn{6}{|c|}{ Model Summary ${ }^{b}$} \\
\hline $\begin{array}{l}\text { Mod } \\
\text { el }\end{array}$ & $\mathrm{R}$ & $\begin{array}{c}\mathrm{R} \\
\text { Squar } \\
\mathrm{e}\end{array}$ & $\begin{array}{l}\text { Adjuste } \\
\text { d R } \\
\text { Square }\end{array}$ & $\begin{array}{l}\text { Std. Error } \\
\text { of the } \\
\text { Estimate }\end{array}$ & $\begin{array}{l}\text { Durbin- } \\
\text { Watson }\end{array}$ \\
\hline 1 & $\begin{array}{r}.641 \\
\mathrm{a}\end{array}$ & ,411 & ,403 & 3,172624 & 1,933 \\
\hline $\begin{array}{l}\text { a. } \operatorname{Pre} \\
\text { b. De }\end{array}$ & $\begin{array}{l}\text { ctor } \\
\text { nde }\end{array}$ & $\begin{array}{l}\text { Const } \\
\text { Tarial }\end{array}$ & $\begin{array}{l}\text { LPTOT } \\
\text { KPTOT }\end{array}$ & , IHTOT & \\
\hline
\end{tabular}

Dari hasil penghitungan yang dilakukan berdasarkan tabel 3, diperoleh nilai DurbinWatson sebesar 1,933. Karena, DW > dU atau $1,933>1,760$, maka tidak ada autokorelasi positif. $4-\mathrm{DW}<\mathrm{dL}$ atau $2,067<1,706$, maka ada autokorelasi negatif.

b. Uji Heteroskedastisitas

Uji heterokedastisitas digunakan untuk mengetahui ada atau tidaknya penyimpangan asumsi klasik heterokedastisitas yaitu adanya ketidaksamaan varian dari residual untuk semua pengamatan pada model regresi.

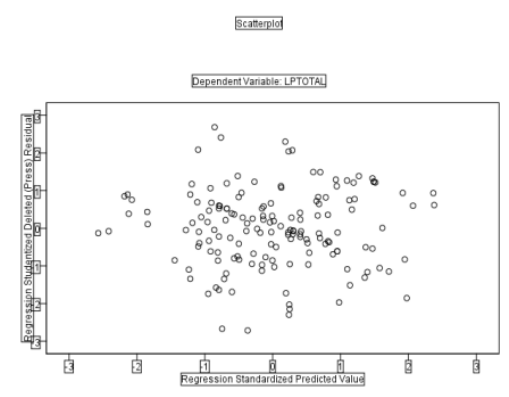

Gambar 4

Hasil Uji Heterokedastisitas Sub-Struktur 1

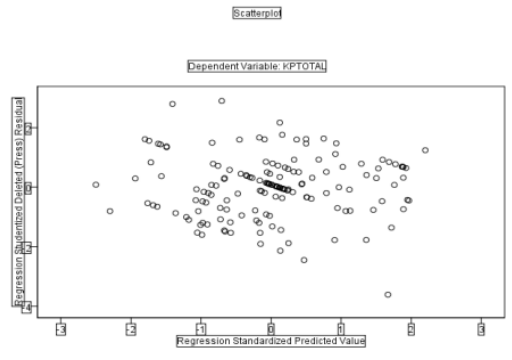

Gambar 5.

Hasil Uji Heterokedastisitas Sub-Struktur 2

Dari hasil pengujian pada gambar 4 dan 5 menunjukkan bahwa tidak terdapat pola yang jelas dari titik-titik tersebut. Pada gambar 4 dan 5 titik-titik menyebar di atas angka 0 dan di bawah pada sumbu Y. Hal ini menunjukkan bahwa model regresi tidak memiliki gejala adanya heteroskedastisitas, yang berarti bahwa tidak ada gangguan yang berarti dalam model regresi ini.

\section{c. Uji Linieritas}

Linieritas adalah keadaan dimana hubungan antara variabel dependen dengan variabel independen bersifat linier (garis lurus) dalam range variabel independen tertentu. Uji linieritas bertujuan untuk mengetahui apakah dua variabel memiliki hubungan linier atau tidak secara signifikan.

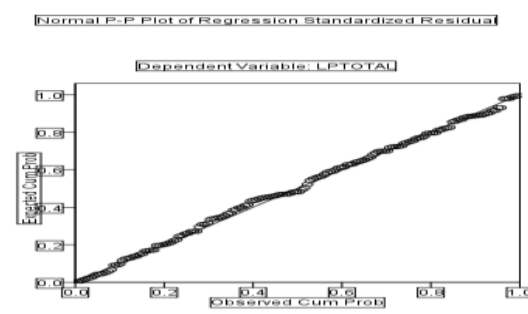

Gambar 6

Hasil Uji Linieritas Sub-Struktur 1

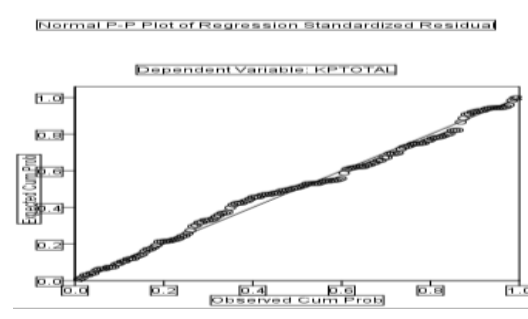

Gambar 7

Hasil Uji Linieritas Sub-Struktur 2

Dari gambar 6 dan 7 di atas terlihat bahwa data sudah membentuk garis lurus dari sisi kiri bawah ke kanan atas sesuai dengan teori linieritas, sehingga dapat disimpulkan bahwa linieritas dalam model regresi ini sudah terpenuhi. 
d. Pengujian Hipotesis

Untuk melakukan peengujian ketepatan prediktor (variabel exogenous) yang digunakan untuk memprediksi variabel endogenous dapat digunakan angka standard deviation dan angka standard error of estimate, dengan ketentuan sebagai berikut: 1) Jika standard error of estimate $<\quad$ standard deviation, maka predictor layak/benar. 2) Jika standard error of estimate > standard deviation, maka predictor tidak layak/salah. Hasil pengujian ketepatan predictor dapat dilihat pada tabel 4 berikut:

Tabel 4.

Descriptive Statistics Sub-Struktur 1

\begin{tabular}{llll}
\hline Descriptive Statistics & & & \\
\hline & Mean & Std. & $\mathrm{N}$ \\
& & Deviation & \\
Loyalitas Pelanggan & 88,32423 & 16,858844 & 156 \\
Iklan Humor & 66,75689 & 8,786063 & 156 \\
\hline
\end{tabular}

Tabel 5.

Model Summary Sub-Struktur 1

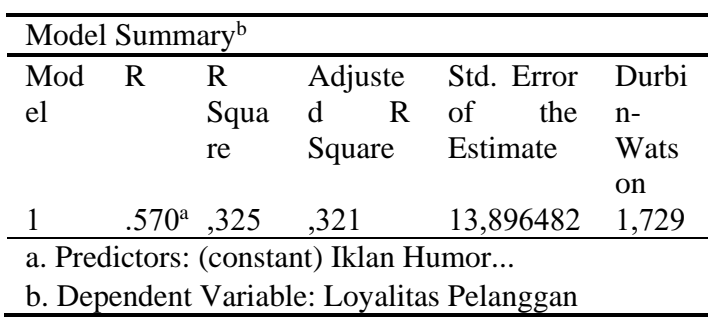

Dari kedua tabel di atas diperoleh nilai standard deviation sebesar 16,858844 dan nilai standard error of estimate sebesar 13,896482. Karena standard error of estimate < standard deviation atau $13,896482<16,858844$, maka dapat disimpulkan bahwa predictor yang digunakan dalam penelitian layak atau benar untuk digunakan.

Tabel 6.

Descriptive Statistics Sub-Struktur 2

\begin{tabular}{llll}
\hline \multicolumn{2}{l}{ Descriptive Statistics } & & \\
\hline & Mean & $\begin{array}{l}\text { Std. } \\
\text { Deviation } \\
\text { Keputusan }\end{array}$ & $\mathrm{N}$ \\
Pembelian & 19,35127 & 4,107664 & 156 \\
Iklan Humor & 66,75689 & 8,786063 & 156 \\
Loyalitas & 88,32423 & 16,858844 & 156 \\
Pelanggan & & & \\
\hline
\end{tabular}

Tabel 7.

Model Summary Sub-Struktur 2

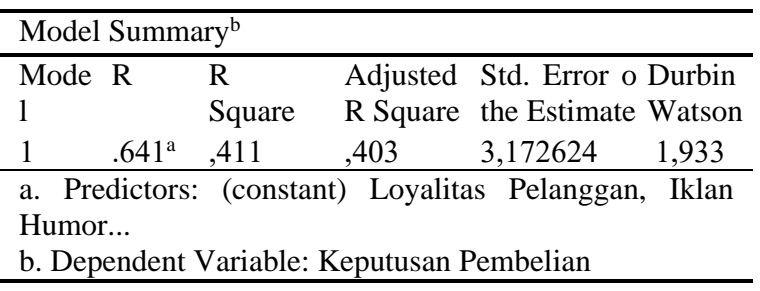

Dari kedua tabel di atas diperoleh nilai standard deviation sebesar 8,786063 (variabel Iklan Humor) dan 4,107664 (variabel Keputusan Pembelian) dan nilai standard error of estimate sebesar 3,172624. Karena standard error of estimate < standard deviation atau 3,172624 < 8,786063 dan 4,107664, ini dapat disimpulkan bahwa kedua prediktor yang digunakan dalam penelitian layak atau benar untuk digunakan.

\section{Menentukan korelasi antara X1-X2, X2-X3 dan X1-X3}

Untuk mengetahui korelasi antara variabel independen exogenous Iklan Humor dengan variabel dependen endogenous Loyalitas Pelanggan (X1-X2). Juga mengetahui variabel independen exogenous Loyalitas Pelanggan dengan variabel dependen endogenous Keputusan Pembelian (X2-X3) dan variabel independen exogenous Iklan Humor dengan variabel dependen endogenous Keputusan Pembelian (X1$\mathrm{X} 3$ ). Lebih jelas untuk mengetahui nilai dari koefisien korelasi antara ketiga variabel secara parsial dapat dilihat pada tabel di berikut ini:

Tabel 8.

Correlations Sub-Struktur 2

\begin{tabular}{|c|c|c|c|c|}
\hline \multicolumn{5}{|l|}{ Correlations } \\
\hline \multirow{6}{*}{$\begin{array}{l}\text { Pearson } \\
\text { Correlation }\end{array}$} & & KeputusanP & klan & Loyalitas \\
\hline & & zmbelian & Iumor & Pelanggan \\
\hline & Keputusan & 1,000 & ,403 &, 639 \\
\hline & Pembelian & & & \\
\hline & Iklan Humor & ,403 & 1,000 &, 570 \\
\hline & Loyalitas & 639 &, 570 & 1,000 \\
\hline \multirow{5}{*}{$\begin{array}{l}\text { Significanc } \\
\text { e (1-tailed) }\end{array}$} & Pelanggan & & & \\
\hline & Keputusan & . &, 000 &, 000 \\
\hline & Pembelian & & & \\
\hline & Iklan Humor & ,000 & &, 000 \\
\hline & Loyalitas & ,000 & ,000 & . \\
\hline & Pelanggan & & & \\
\hline \multirow[t]{5}{*}{$\mathbf{N}$} & Keputusan & 156 & 156 & 156 \\
\hline & Pembelian & & & \\
\hline & Iklan Humor & 156 & 156 & 156 \\
\hline & Loyalitas & 156 & 156 & 156 \\
\hline & Pelanggan & & & \\
\hline
\end{tabular}

Untuk menginterpretasikan nilai koefisien korelasi digunakan kriteria (Sarwono, 2006):

$$
\begin{array}{ll}
0 & =\text { tidak ada korelasi } \\
>0-0,25 & =\text { korelasi sangat lemah } \\
>0,25-0,50 & =\text { korelasi cukup } \\
>0,50-0,75 & =\text { korelasi kuat } \\
>0,75-0,99 & =\text { korelasi sangat kuat } \\
1 & =\text { Korelasi sempurna }
\end{array}
$$

Dalam penelitian ini masih banyak keterbatasan yaitu hanya menggunakan beberapa variabel, antara lain iklan humor, loyalitas pelanggan dan keputusan pembelian. Pengaruh dari variabel yang telah di analisis mempunyai korelasi yang cukup kuat. Namun ada juga variabel yang mempunyai 
korelasi yang kurang signifikan. Obyek penelitian yang lebih populer bagi responden akan memudahkan peneliti dalam mendapatkan data primer. Setelah adanya penelitian ini diharapkan dapat melengkapi wawasan tenaga pemasar dalam memasarkan produk. Selain itu perlu adanya peningkatan kreatifitas guna menarik perhatian konsumen. Menggunkan unsur humor dalam periklanan terbukti menjadi salah satu cara efektif guna dapat meningkatkan efek positif bagi penjualan. Produk yang berkualitas akan dapat meningkatkan keputusan pembelian. Untuk penelitian selanjutnya bisa menambah variabelvariabel yang relevan serta indikator yang lebih kompleks.

\section{KESIMPULAN}

Berdasarkan analisis data yang telah dilakukan, berikut ini disampaikan beberapa kesimpulan yang relevan dengan hasil analisis data tersebut.

a. Iklan humor Axis versi kembalian yang tayang di televisi banyak disukai dan mempunyai pengaruh yang cukup terhadap keputusan pembelian, korelasi pengaruh tersebut sebesar $40 \%$.

b. Pelanggan Axis yang loyal dan puas atas segala layanan akan tetap menggunakan produk tersebut bahkan signifikan akan melakukan pembelian ulang, korelasi pengaruh tersebut sebesar $64 \%$.

c. Iklan yang menarik dan mempunyai unsur humor hampir $50 \%$ responden menyukai, hal ini dapat peningkatan daya tarik pengguna dan akan berpengaruh terhadap loyalitas pelanggan, korelasi pengaruh tersebut sebesar $57 \%$.

Iklan humor Axsis versi kembalian dan loyalitas pelanggan berdasarkan analisis secara menyeluruh yang telah dilakukan, tidak mempunyai pengaruh yang positif dan signifikan terhadap keputusan pembelian. Pengaruh atas hitungan parsial tersebut hanya sebesar $5 \%$.

\section{REFERENSI}

Kothler, Philip dan Garry Amstrong. (2014) Prinsip-prinsip Pemasaran edisi Kelima Belas (Jilid 1) Jakarta: Erlangga.

Mirandha, Ira Yuni Mirandha dan Adi Bayu Mahadian. (2017). Perbandingan Persepsi Khalayak antara iklan yang mengandung humor dan tidak mengandung humor. Profesi Humas. Jurnal Ilmiah Ilmu Hubungan Masyarakat, Volume 1, No. 2, Februari 2017, hlm. 112-123

Morrisan,. (2010). Periklanan: Komunikasi Pemasaran Terpadu. Edisi Pertama. Jakarta: Kencana Prenada Media Group.

Sarwono, Jonathan. (2012). Path Analysis. Jakarta: PT. Elex Media Komputindo.

Sugiyono. (2014). Metode penelitian manajemen: pendekatan, kuantitatif, kualitas, kombinasi, penelitian tindakan. Yogyakarta: Alfabeta.

Tahuman, Zainuddin. (2016). Analisis FaktorFaktor Yang Mempengaruhi Loyalitas Pelanggan Serta Dampaknya Terhadap Keunggulan Bersaing. Jurnal Riset Bisnis dan Manajemen Vol 4 ,No.3, Edisi Khusus Pemasaran \& Keuangan 2016: 445-460

Yunita, Dessy. Eko Fitrianto \& Nofiawaty. (2017). Tema Humor Pada Iklan Serta Pengaruhnya Terhadap Pemahaman Pesan Iklan dan Buying Readiness Stage. Jurnal Manajemen dan Bisnis Sriwijaya Vol.15 (2)

\section{PROFIL PENULIS}

Slamet Maryoso adalah Dosen di Universitas BSI Jakarta dan mulai mengajar sejak bulan Juli tahun 2010. Sebelumnya ia bekerja sebagi Penyiar dan Reporter Radio Swasta di Madiun, Jakarta dan Purwakarta. 